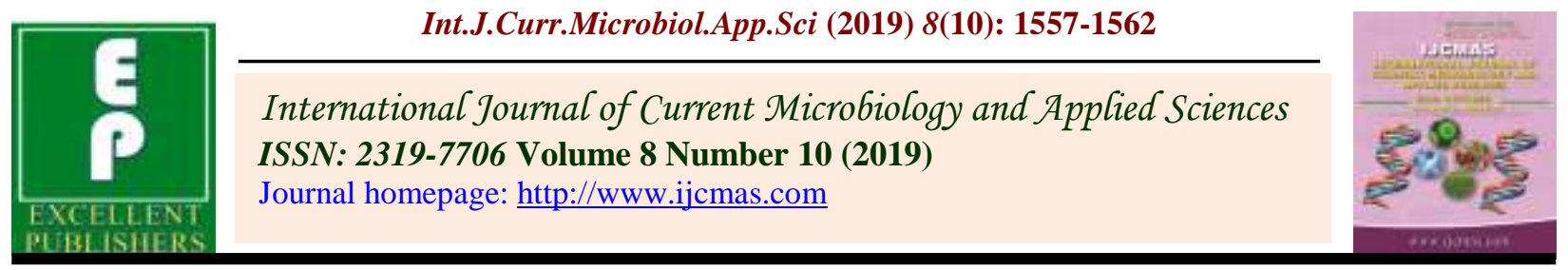

Original Research Article

https://doi.org/10.20546/ijcmas.2019.810.181

\title{
Growth, Yield and Quality of Sugarcane Influenced by Row Spacing and Plant Geometry under Sub Surface Drip Fertigation System
}

\author{
P. Christy Nirmala Mary ${ }^{1 *}$, A. Anita ${ }^{2}$ and M. Jeyachandran ${ }^{2}$ \\ ${ }^{1}$ Department of Soils and Environment Agricultural College and Research Institute, \\ Madurai -625104, India \\ ${ }^{2}$ Sugarcane Research Station, Cuddalore, India \\ *Corresponding author
}

\section{A B S T R A C T}

Keywords

Row spacing, Water soluble fertilizers,

Double side planting, Fertigaion, Sub surface drip

Article Info

Accepted:

12 September 2019 Available Online: 10 October 2019

\begin{abstract}
Sugar cane is one of the most important field crops in the tropics. Sugarcane is grown is not less than 105 countries and presently it covers a total acreage of about 19 million hectares for a world production of approximately 1.3 billion metric ton of cane and 127 million ton of sugar. Sub surface drip irrigation is the most advanced method of irrigation, which enables the application of small amounts of water to soil through the drippers placed below the soil surface with discharge rates. Row spacing has a direct effect on plant population. It plays a distinct role in the amount of solar radiation intercepted and density, hence, crop canopy development which in turn affects photosynthesis and ultimately the dry matter produced by plant. Based on this view, field experiment was carried out at Sugarcane Research Station, Cuddalore to optimize the row spacing and plant geometry for mechanized cane cultivation under sub surface drip fertigation system. Sugarcane variety viz., CoC 24 was in ten row spacing's of 120,135,150, and $180 \mathrm{~cm}$ with each in single side and double side planting treatments were applied. A Randomized block design with three replications was used. Results revealed that widening spaces between rows of sugarcane from 120 up to $180 \mathrm{~cm}$ resulted in a significant and gradual increase in bio metric observation and yield parameters. Row spacing at $120 \mathrm{~cm}$ with double side planting gave the highest values of cane yield, juice quality and commercial cane sugar. The double side planting registered more tiller population than single side planting. The double side planting registered more cane yield. Among the treatments, the maximum cane yield of $155.35 \mathrm{t} / \mathrm{ha}$ was observed in the treatments by the row spacing of $120+40 \mathrm{~cm}$ double side planting.
\end{abstract}

\section{Introduction}

Sugar cane is one of the most important field crops in the tropics. Sugarcane is grown is not less than 105 countries and presently it covers a total acreage of about 19 million hectares for a world production of approximately 1.3 billion metric ton of cane and 127 million ton of sugar. Fertigation has been described as the application of plant nutrients in irrigation water to accomplish fertilization. Many researchers indicated that the beneficial effect 
of fertigation increasing the efficiency of nutrients utilization under drip fertigation system.

Sub surface drip irrigation Is the most advanced method of irrigation, which enables the application of small amounts of water to soil through the drippers placed below the soil surface with discharge rates (Risz. et al., 2004). Row spacing has a direct effect on plant population. It plays a distinct role in the amount of solar radiation intercepted and density, hence, crop canopy development which in turn affects photosynthesis and ultimately the dry matter produced by plant. Also, it may affect cane diameter, length and weight which contribute to cane yields. Sugarcane planted at a row spacing of $75 \mathrm{~cm}$ gave significantly higher cane yield compared to $90 \mathrm{~cm}$ row spacing (Avtar et al., 2001). Narrow row spacing $(100 \mathrm{~cm})$ produced higher number of millable canes, cane and sugar yields compared to 120 and $140 \mathrm{~cm}$ row spacing. Their results showed that the wider row spacing $(140 \mathrm{~cm})$ significantly recorded thicker stalks, compared with those of narrower spacing of $100 \mathrm{~cm}$.Juice quality traits were not significantly affected by spacing. Cane girth and number of millable canes were significantly higher with a $90 \mathrm{~cm}$ intra-row spacing compared with 30 or $60 \mathrm{~cm}$ intra-row spacing. Millable cane height and average number of internodes/plant were not significantly affected by spacing. Sucrose was insignificantly affected by the studied row distances (100, 120 and $140 \mathrm{~cm}$ ) (Rizk et al., 2004). The widest row distance significantly gave the thickest stalks (Raskar et al., 2003).

Growing sugarcane in rows of $80 \mathrm{~cm}$ apart attained a significant increase in stalk height, number of millable canes, cane and sugar yields. However, stalk diameter increased with $120 \mathrm{~cm}$ spacing (EL-Shafai and Ismail, 2006). Sucrose and sugar recovery percentages were insignificantly affected by row spacing. The highest number of millable canes (128000/ha) and cane yield (62.9 tons/ha) were recorded at $45 \mathrm{~cm}$ spacing followed by $60 \mathrm{~cm}(119400 / \mathrm{ha}$ and 58.2 tons/ha) and $75 \mathrm{~cm}$ (112300/ha and 55.0 tons/ha). Planting sugarcane in rows spaced at $80 \mathrm{~cm}$ attained significant increases in millable cane length, number of millable cane, cane and sugar yields, compared with 100 and $120 \mathrm{~cm}$ spacing (Singh et al., 2001). The aim of the present work was to find out the best row spacing and effective planting geometry to obtain the highest yield and quality of sugarcane.

\section{Materials and Methods}

The experiment was conducted at sugarcane Research Station, Cuddalore during December 2009 using sub surface drip irrigation system. The soil of the experimental site was deep, sandy clay loam with neutral pH 7.6, EC 0.08 $\mathrm{dS} \mathrm{m}^{-1}$ and organic carbon $0.09 \%$. The available nitrogen, $\mathrm{P}$ and $\mathrm{K}$ were 192, 13, 250 $\mathrm{kg} /$ ha respectively. The water holding capacity for corresponding depths was $25 \%$. Before cultivation, drip tubing was buried $10 \mathrm{~cm}$ deep directly under the soil beds. Sugarcane setts were planted in to soil beds in different row spacing. Water requirement was scheduled based on evaporation replenishment. (0.75 class pan evaporation) Irrigation frequency was running on alternate days for a period of two hours over the four month duration of experiment included 12 irrigation events with fertigation. The experiment was arranged in randomized block design consisting of ten row spacings with single side and double side plantings. The sets were planted on both sides of the furrows as well as in a single row. The seed rate adopted was 8 two budded sets per running meter and this was uniform for both double side and single side plantings. The 100 $\%$ water soluable fertilizers fertigation were applied on 15 days intervals. The fertilizer schedule was $275: 65: 113$. $\mathrm{kg} \mathrm{N}, \mathrm{P}_{2} \mathrm{O}_{5}$ and $\mathrm{K}_{2}$ $\mathrm{O} / \mathrm{ha}$. All nitrogen and potassium fertilizers 
were injected directly in to the irrigation water using injector.The yield were recorded along with the quality parameters.

\section{Results and Discussion}

The growth characters, yield and yield attributes characters were recorded and the results are presented in the Table 1.

\section{Tiller population}

In the $90^{\text {th }}$ day tiller population, maximum of $2,26,765$ tillers/ha was registered by the row spacing of $120+40 \mathrm{~cm}$ DS followed by the row spacing of $135+40 \mathrm{~cm}$ DS with 2,21,461 tillers/ha. The double side planting registered more tiller population than single side planting. Among the single row planting, the spacing of $135+30 \mathrm{~cm}$ produced the maximum of 1,65,993 tillers /ha. These results could be due to the competition among cane plants grown in narrower rows for growth elements, i.e., nutrients, water and sun light. Chang (1974) explained that the proportion of invisible solar radiation is so much increased than the visible solar radiation due to dense sowing.

\section{Millable cane population}

Double side planting at the spacing of $120+40$ $\mathrm{cm}$ produced the maximum shoot population of $1,19,240$ /ha followed by $135+40 \mathrm{~cm}$ with double side 103085 shoots /ha.

\section{Cane yield}

The double side planting registered more cane yield. Among the treatments, the maximum cane yield of $135.35 \mathrm{t} / \mathrm{ha}$ was observed in the treatments by the row spacing of $120+40 \mathrm{~cm}$ double side planting followed by the row spacing of $135+40$ double side planting $129.33 \mathrm{t} / \mathrm{ha}$. These results could be attributed to the increase in number of millable canes as row spacing decreased. These results are in agreement with those reported by El-Shafai (2002). The Higher cane yield at $120 \mathrm{~cm}$ spaced planting might be attributed to higher values of yield contributing parameters like cane length, cane weight and cane diameter. These results are in line with Bashir et al., (2005) who reported that a row spacing of 120 $\mathrm{cm}$ was found optimum for higher cane yields.

\section{Commercial cane sugar $(\%)$}

Double side planting at the spacing of $120+40$ $\mathrm{cm}$ under double side planting registered the CCS of $13.22 \%$ followed by $135+40 \mathrm{~cm}$ with double side planting of $13.20 \%$. This huge difference in sucrose content might be due to climatic changes, as high rainfall was noted during the growth period of the crop that resulted in high water contents in the cane juice and lesser sucrose content.

The plant crop was taken up with test variety $\mathrm{CoC}$ (SC) 24 with different row spacing from $120 \mathrm{~cm}$ to $180 \mathrm{~cm}$. The sets were planted on both sides of the furrows as well as in a single row. A seed rate of 8 two budded sets per running meter was adopted and it was uniform for both double side and single side plantings. Regarding double side planting at the spacing of $120+40 \mathrm{~cm}$ produced the maximum shoot population of $1,19,240$ /ha followed by $135+40 \mathrm{~cm}$ with double side $1,03,085$ shoots /ha. The double side planting at a spacing of $120+40 \mathrm{~cm}$ produced the maximum mean cane yield of $155.35 \mathrm{t}$ /ha followed by the lateral spacing of $135+40 \mathrm{~cm}(149.33 \mathrm{t} / \mathrm{ha}$.). The CCS content ranged from 10.88 to 12.15 $\%$.The CCS content was observed to be higher $(12.15 \%)$ in the treatment of $150 \mathrm{~cm}$ lateral spacing as double side planting.

The millable cane population, cane yield and CCS content were recorded for first ratoon crop. The results on yield and yield attributes are presented in Table 2 . 
Table.1 Treatment details

\begin{tabular}{|l|}
\hline$T_{1}-$ Lateral spacing at $120 \mathrm{~cm} \mathrm{SSP}$ \\
\hline$T_{2}-$ Lateral spacing at $120 \mathrm{~cm} \mathrm{DSP}$ \\
\hline$T_{3}-$ Lateral spacing at $130 \mathrm{~cm} \mathrm{SSP}$ \\
\hline$T_{4}-$ Lateral spacing at $130 \mathrm{~cm} \mathrm{DSP}$ \\
\hline$T_{5}-$ Lateral spacing at $150 \mathrm{~cm} \mathrm{SSP}$ \\
\hline$T_{6}-$ Lateral spacing at $150 \mathrm{~cm} \mathrm{DSP}$ \\
\hline$T_{7}-$ Lateral spacing at $165 \mathrm{~cm} \mathrm{SSP}$ \\
\hline$T_{8}-$ Lateral spacing at $165 \mathrm{~cm} \mathrm{DSP}$ \\
\hline$T_{9}-$ Lateral spacing at $180 \mathrm{~cm} \mathrm{SSP}$ \\
\hline$T_{10}-$ Lateral spacing at $180 \mathrm{~cm} \mathrm{DSP}$ \\
\hline
\end{tabular}

Design : Randomised Block Design

SSP- Singe Side Planting

Replication :Three

DSP- Double Side Planting

Table.2 Effect of row spacing on growth characters and yield attributes

\begin{tabular}{|c|c|c|c|c|}
\hline $\begin{array}{c}\text { SI } \\
\text {.No. }\end{array}$ & Treatments & $\begin{array}{c}\text { Millable cane } \\
\text { population } \\
(000 \text { 's /ha ) }\end{array}$ & $\begin{array}{c}\text { Cane yield } \\
\text { (t/ha) }\end{array}$ & C.C.S (\%) \\
\hline 1. & Lateral spacing at $120 \mathrm{~cm} \mathrm{SSP}$ & 96.37 & 128.37 & 11.17 \\
\hline 2. & $\begin{array}{l}\text { Lateral spacing at } 120 \mathrm{~cm} \\
\text { DSP }\end{array}$ & 119.24 & 155.35 & 11.62 \\
\hline 3. & Lateral spacing at $130 \mathrm{~cm} \mathrm{SSP}$ & 93.33 & 124.90 & 11.48 \\
\hline 4. & $\begin{array}{l}\text { Lateral spacing at } 135 \mathrm{~cm} \\
\text { DSP }\end{array}$ & 103.09 & 149.33 & 11.58 \\
\hline 5. & Lateral spacing at $150 \mathrm{~cm} \mathrm{SSP}$ & 95.37 & 122.58 & 11.68 \\
\hline 6. & $\begin{array}{l}\text { Lateral spacing at } 150 \mathrm{~cm} \\
\text { DSP }\end{array}$ & 94.64 & 139.28 & 12.15 \\
\hline 7. & Lateral spacing at $165 \mathrm{~cm} \mathrm{SSP}$ & 81.39 & 118.57 & 11.85 \\
\hline 8. & $\begin{array}{l}\text { Lateral spacing at } 165 \mathrm{~cm} \\
\text { DSP }\end{array}$ & 77.34 & 137.38 & 12.03 \\
\hline 9. & Lateral spacing at $180 \mathrm{~cm} \mathrm{SSP}$ & 74.42 & 112.57 & 11.73 \\
\hline 10. & $\begin{array}{l}\text { Lateral spacing at } 180 \mathrm{~cm} \\
\text { DSP }\end{array}$ & 100.32 & 145.29 & 11.78 \\
\hline 11. & $\begin{array}{c}\text { Normal furrow at } 120+40 \mathrm{~cm} \\
\text { DSP }\end{array}$ & 73.38 & 102.67 & 10.88 \\
\hline \multicolumn{2}{|r|}{ SEd } & 9.29 & 11.27 & 0.05 \\
\hline \multicolumn{2}{|r|}{ CD } & 21.93 & 23.23 & 0.12 \\
\hline
\end{tabular}


Table.3

\begin{tabular}{|c|c|c|c|c|}
\hline $\begin{array}{l}\text { Sl. } \\
\text { No. }\end{array}$ & Treatments & $\begin{array}{l}\text { Millable cane } \\
\text { population } \\
\text { (000's /ha) }\end{array}$ & $\begin{array}{l}\text { Cane yield } \\
\text { (t/ha) }\end{array}$ & $\begin{array}{l}\text { C.C.S } \\
(\%)\end{array}$ \\
\hline 1. & Lateral spacing at $120 \mathrm{~cm} \mathrm{SSP}$ & 99.68 & 130.12 & 11.29 \\
\hline 2. & Lateral spacing at $120 \mathrm{~cm}$ DSP & 121.24 & 157.42 & 11.75 \\
\hline 3. & Lateral spacing at $130 \mathrm{~cm} \mathrm{SSP}$ & 93.67 & 126.92 & 11.54 \\
\hline 4. & Lateral spacing at $135 \mathrm{~cm}$ DSP & 119.56 & 152.01 & 11.62 \\
\hline 5. & Lateral spacing at $150 \mathrm{~cm} \mathrm{SSP}$ & 97.89 & 123.27 & 11.75 \\
\hline 6. & Lateral spacing at $150 \mathrm{~cm}$ DSP & 95.25 & 141.17 & 12.23 \\
\hline 7. & Lateral spacing at $165 \mathrm{~cm} \mathrm{SSP}$ & 91.25 & 120.57 & 11.92 \\
\hline 8. & Lateral spacing at $165 \mathrm{~cm}$ DSP & 89.25 & 139.19 & 12.15 \\
\hline 9. & Lateral spacing at $180 \mathrm{~cm} \mathrm{SSP}$ & 82.1 & 115.23 & 11.82 \\
\hline 10. & Lateral spacing at $180 \mathrm{~cm}$ DSP & 112.29 & 147.15 & 11.91 \\
\hline 11. & $\begin{array}{c}\text { Normal furrow at } 120+40 \mathrm{~cm} \\
\text { DSP }\end{array}$ & 79.52 & 104.67 & 10.99 \\
\hline & SEd & 2.84 & 0.64 & 0.004 \\
\hline & CD & 5.93 & 1.38 & 0.0089 \\
\hline
\end{tabular}

The results showed that there was significant difference between row spacing and planting methods. The double side planting at the lateral spacing of $120+40 \mathrm{~cm}$ produced the maximum millable cane population $(1,21,242$ /ha) followed by double side planting at the spacing of $135+40 \mathrm{~cm}(1,19,569 / \mathrm{ha})$. The double side planting at a spacing of $120+40$ $\mathrm{cm}$ produced the maximum mean cane yield of $157.42 \mathrm{t}$ /ha followed by the lateral spacing of $135+40 \mathrm{~cm}$ (152.01 t/ha.) (Table 3). The CCS content ranged from 10.99 to 12.23 $\%$. The CCS content was observed to be higher $(12.23 \%)$ in the treatment of $150 \mathrm{~cm}$ lateral spacing as double side planting.

\section{References}

Avta S, Rajbahadur S, Singh A (2001) Effect of agronomic practices on the productivity of late planted sugarcane. Crop Res Hisar 21 (2): 123-125.

Bashir S, Ali A, Yasin M (2005) Sugarcane varieties and row spacing effect on sugarcane cane varieties ratoon.
Pakistan Sugar J 17 (2): 2-8.

Chang J H, (1974) Radiation distribution within the plant community. Climate and Agriculture, Aldine Publishing Company, Chicago, Illinois, USA. Page No 36-42.

El-Geddawy I H, Darweish D G, El-Sherbiny A. A, El-Hady E E A (2002) Effect of row spacing and number of buds/seed setts on: 3. Yield components of ratoon crops for some sugar traits. Pak Sug J 20:18-20

El-Shafai A M A, Ismail A. M. A. (2006) Effect of row spacing on yield and quality of some promising sugarcane varieties. Egypt J Appl Sci 21 (11): 3246.

Raskar B S, Bhoi P. G (2003) Yield attributes of sugarcane as influenced by intrarow spacings, fertilizer levels and planting materials. Indian Sugar 53 (5): 327-331

Rizk T Y, EL-Agroudy. M, El-Geddawy I H, Fergany M. A (2004) Effect of row distance and cutting size on growth 
criteria of two promising sugar cane varieties and the commercial variety. Egypt J Agric Res 82 (1): 263-276

Singh A. K, Menhi L A L, Prasad S R (2006) Effect of row spacing and nitrogen on ratoon ability of early maturing high sugar genotypes of sugarcane (Saccharum spp.) hybrids. Indian $\mathrm{J}$ Agric Sci 76 (2):108-110.

\section{How to cite this article:}

Christy Nirmala Mary, P., A. Anita and Jeyachandran, M. 2019. Growth, Yield and Quality of Sugarcane Influenced by Row Spacing and Plant Geometry under Sub Surface Drip Fertigation System. Int.J.Curr.Microbiol.App.Sci. 8(10): 1557-1562.

doi: https://doi.org/10.20546/ijcmas.2019.810.181 